\section{Analysis of tuberculosis program management in primary health care}

\author{
Ni Njoman Juliasih, ${ }^{1}$ Soedarsono, ${ }^{2}$ \\ Reny Mareta Sari ${ }^{1}$ \\ ${ }^{1}$ Club Study Tuberculosis, Institute of \\ Tropical Disease, Universitas Airlangga; \\ ${ }^{2}$ Dr. Soetomo General Hospital, \\ Surabaya, Indonesia
}

\begin{abstract}
Background: This study discusses the analysis of Tuberculosis (TB) program management at the Perak Timur Primary Health Care (PHC) and the Sawahan PHC in Surabaya. Early detection and adequate treatment can prevent transmission and improve control programs.
\end{abstract}

Objective: This study aims to analyze management of the tuberculosis program at PHCs in Surabaya.

Methods: The research method used is qualitative research. Data collection was done by interviewing tuberculosis officers about TB program and carrying out observations at the PHCs.

Results: The study showed that case finding in the Perak Timur PHC and the Sawahan PHC was passive-active. The Perak Timur PHC has facilities for rapid molecular testing, while the Sawahan PHC have to go to a center for Health Laboratory if rapid molecular testing is needed. In terms of treatment, patients at the Perak Timur PHC would come according to an agreement with TB officer, while at the Sawahan PHC, patients have to come every Monday. Officer at the Perak Timur PHC tended to accommodate the needs of TB patients compared to officer at the Sawahan PHC. The level of adherence to taking medication in two PHCs is good but there are a number of patients who have not really understood the frequency of taking medication.

Conclusion: Generally, both PHCs have good TB program management but the Perak Timur PHC tends to be more flexible towards patients while the Sawahan PHC tends to be stricter towards patients.

\section{Introduction}

Tuberculosis (TB) is one of the top 10 causes of death worldwide. In 2017, 10 million people got infected by TB and 1,6 million died from the disease. Indonesia is one of the eight countries that counted for two thirds of the new TB case alongside India, China, The Philippines, Pakistan, Nigeria, Bangladesh and South Africa. ${ }^{1}$

Therefore, to overcome the problem of TB, in 1993, the World Health Organization (WHO) declared TB a global emergency and introduced the directly observed treatment, short-course (DOTS), a strategy for global TB control. ${ }^{2}$ In 1995, the national TB control program in Indonesia began to implement the DOTS strategy, which was carried out at the primary health care (PHC) facilities gradually. In 2000, the DOTS strategy was implemented nationally in all health care services, especially PHC, where it was integrated with basic health services. ${ }^{3}$

PHC is a first-level health service implementing unit. There are three functions of the PHC: it functions as a first-level health service center, as center for the development of health-oriented development, and as a center for community and family empowerment. In carrying out its activities, the PHC refers to the four principles of implementation, namely the work area, community empowerment, integration, and referrals. ${ }^{4}$

PHC are the spearhead of government health services. PHC have work areas and deal directly with families in their homes. Therefore, if something goes wrong with health problems in the community, the $\mathrm{PHC}$ will be the most responsible party in it. However, in its implementation the PHC has limited resources in terms of energy, cost, and facilities. This is a challenge for each PHC: to assume a large responsibility with limited resources. One effort to answer this challenge is to manage the available resources as well as possible. Thus, it is absolutely necessary that adequate management functions in its management including in carrying out the DOTS strategy. ${ }^{5}$

There are five components in the DOTS strategy, namely: 1. Political commitment from the government to run a national TB program. 2. Diagnosis of TB through sputum examination microscopically. 3 . Treatment of TB with a combination of Anti-Tuberculosis Drugs (ATD), which is supervised directly by the Drugs Drinking Supervisor. 4. ATD inventory continuity. 5 . Standard recording and reporting to facilitate monitoring and evaluation of the Pulmonary TB prevention program. ${ }^{6}$

TB case treatment is one of the DOTS strategies that are able to control TB, because it can break the chain of disease transmission. Although the National TB Control Program has succeeded in achieving the target number of findings and cure rates, TB management in most PHC, hospitals, and private practices is not in accor-
Correspondence: Ni Njoman Juliasih, Club Study Tuberculosis Institute of Tropical Disease Universitas Airlangga, Kampus C Mulyorejo Surabaya 60115, Indonesia. Tel.: +628113642237

E-mail: njomanjuliasih@staf.unair.ac.id

Key words: Analysis, management, tuberculosis, program, primary health care

Contributions: All the authors contributed equally.

Conflict of interests:The authors declare no conflict of interest.

Funding: Self funding.

Acknowledgements: The authors thank the staff of the Sawahan PHC and the Perak Timur $\mathrm{PHC}$ for their data support.

Conference presentation: The article had been presented an international conference Infectious Diseases, Biothreats, and Military Medicine (INSBIOMM) at 2019 August 2728, Surabaya, Indonesia.

Received for publication: 17 February 2020. Accepted for publication: 1 July 2020.

This work is licensed under a Creative Commons Attribution-NonCommercial 4.0 International License (CC BY-NC 4.0).

COCopyright: the Author(s), 2020

Licensee PAGEPress, Italy

Infectious Disease Reports 2020; 12(s1):8728

doi:10.4081/idr.2020.8728

dance with the DOTS strategy and application of service standards based on the International Standards for Tuberculosis Care. ${ }^{7}$ There are a number of factors that influence the implementation of the TB program at PHC: i.e. weak recording systems, inadequate diagnoses, poorly trained officers, and the presence of stigma from the community. ${ }^{8,9}$ Weak infrastructure, negligence of care providers, lack of information related to TB in the community, and weakness of laboratory quality assurance are all factors that influence TB case finding. ${ }^{9}$

Because of the important role of TB programs in public health and the presence of several influencing factors, it is necessary to analyze how TB programs are carried out in PHCs. This study aims to analyze how the TB program is run in PHCs in Surabaya.

\section{Materials and Methods}

This study used qualitative research 
methods. Primary data were collected through in-depth interviews with informants who are TB officers and through observation at the Perak Timur PHC and the Sawahan PHC in Surabaya. Data validity test was done by doing triangulation between researchers. The triangulation was done by using two people to collect and analyze the data then match the data obtained from two people.

\section{Results and Discussion}

\section{Tuberculosis Case Finding}

The discovery of suspected TB in the community is done actively and passively. Passive discovery was made with patients who came to the PHC to check themselves when experiencing symptoms of TB and with referral from a private clinic. Active case finding was carried out through screening when conducting preventive promotive activities such as counseling. The presence of health cadres makes finding TB suspects easier because cadres play a role in contact tracing. The cadre traces a number of people who were in frequent contact with patients who had symptoms of $\mathrm{TB}$, then refers them to the PHC for an examination. Active discoveries are also made in special cases such as groups of people with HIV, children, the elderly, diabetes mellitus sufferers, and those who come in contact with Multi-Drug Resistant (MDR) TB patients.

Cadres at Sawahan PHC conduct contact tracing of families and neighbors of new pulmonary TB sufferers while TB cadres at the Perak Timur PHC also track people who frequently interact with sufferers even though they live far from sufferers' homes. The number of contacts referred to ranges from 15 to 20 people. Case finding efforts carried out at the Perak Timur PHC were in accordance with national guidelines for tuberculosis prevention.

The importance of the role of cadres in TB case finding is influenced by knowledge and training factors. ${ }^{10}$ Thus, to optimize TB case finding, cadres were trained on TB symptoms, procedures for referring, and contact criteria for referrals.

\section{Diagnosis}

Sputum examination for diagnosis is done by collecting two sputum specimens during the two days of the visit: the first time a sample is collected when the patient comes to visit; upon returning home, suspects bring sputum pots to collect morning phlegm on the second day. Instead in the Sawahan PHC, sputum examination for diagnosis is carried out by collecting two sputum specimens on the same day. On the first day of the visit, patients at the Sawahan PHC received a diagnosis from the doctor based on symptoms and on the second day only sputum specimens are collected for microscopic examination.

The Perak Timur PHC is a Microscopic Referral Health Center so that the examination of molecular rapid tests can be done directly there. A molecular rapid test is performed to determine whether TB bacteria are drug resistant. This examination is carried out if there is a conversion failure in the sputum test at the beginning of month 5 of TB treatment. The Sawahan PHC must conduct molecular rapid test at a center for Health Laboratory because it is not a Microscopic Referral Health Center. Based on the explanation above, the Sawahan PHC is defined a Satellite structure.

Molecular rapid test is the latest discovery method for TB diagnosis based on molecular examination that uses a semiquantitative real time polymerase chain reaction assay (RT-PCR) method and targets the rpoB gene hotspot area in Mycobacterium tuberculosis, which is integrated and automatically processes preparations with extraction of DNA in a disposable cartridge. Molecular rapid test is an effort to accelerate TB control in Indonesia. The use of TB molecular rapid test can accelerate the diagnosis of suspected TB and resistant $\mathrm{TB}$ so that patients can be diagnosed and treated as early as possible. ${ }^{11,12}$

\section{Treatment}

The TB treatment process is carried out according to the regulations and classification of the disease. Patients take drugs regularly according to the agreement between the patient and the TB officer. In general, patients come once a week to take medicine supplies for the week ahead, but in certain situations patients will ask for stock of drugs covering more than one week, such as when patients will go out of town. The National TB Control Guidelines state that taking drugs is not the duty of the drugs drinking supervisor, but in the Perak Timur $\mathrm{PHC}$, the drugs drinking supervisor is often in charge of getting medicine for patients.

In certain situations when the patient is outside the city or even outside the province and in a condition of running out of medicine, the patient will contact the PHC and later the PHC will contact the city health office to be get in touch with the health office and the nearest PHC from where the patient is located. Thus the patient can continue to take medication even though it is outside the working area of the Perak Timur PHC.
A number of efforts were made to improve medication adherence and prevent drop out, including counseling after TB diagnosis, and the drugs drinking supervisor is a respected by patients and coordinates with the village, the sub-district, and the municipal police. At the Sawahan PHC The patients have to collect the drug every Monday and TB officers only provide drug stock for 1 week. The party who takes the drugs from PHC does not have to be the TB patient: they can be taken by the drugs drinking supervisor or a member of the patient's family.

The TB officer at the Sawahan PHC stated that he had never experienced a condition where the patient was out of town and thus out of stock of the drug. Based on field observations, there was actually one incident where there was a patient who wanted to move out of the city, but because of the complexity in taking care of the administration, the patient said he would come to the PHC once a month.

TB officers at the Sawahan PHC and the Perak Timur PHC said that the patients' level of adherence in taking medication was good but there were some patients who still did not understand the duration of taking the medicine. Based on the observation, many patients interpret the drug at the intermittent stage 2 times a day, whereas the drug should be taken three times a week.

Based on the review above, the Perak Timur PHC has implemented the DOTS strategy of coordination with the government. But in the case of taking drugs, the PHC provide leeway by letting the drugs drinking supervisor get the medicine if the patient is unable to attend. This is not in accordance with the national of TB countermeasure guidelines which state that the drugs drinking supervisor is not in charge of taking drugs. ${ }^{7}$

\section{Anti TB Drug Availability}

The Perak Timur PHC said that once it had run out of anti TB drugs stock, the TB officer would make a list of drug needs and then submit it to the PHC pharmacy department. Furthermore, the PHC's pharmacy will borrow medicines from other PHC to overcome the shortage of the drugs. The Sawahan PHC officials said that they have never experienced an out of stock of drugs because the pharmacy will submit a drug request before it runs out. The action done by PHC in overcoming the ATD stock is a common practice by PHC. ${ }^{13}$

Coordination with the pharmacy is easier to do at the Sawahan PHC because the PHC does not have separate TB room so that the location for taking TB drugs is one with the pharmacy. The Perak Timur PHC 
has a separate TB room located on the 2 nd floor with access to the stairs which is also separated from other patients to avoid transmission. For MDR TB patients, treatment at the Perak Timur PHC is carried out at hamlet hall, while at the Sawahan PHC MDR-TB patients are referred to the hospital. Separation of treatment sites is done to minimize the risk of MDR-TB transmission to $\mathrm{TB}$ patients and other patients at the PHC. Basically, MDR-TB occurs due to inadequate $\mathrm{TB}$ treatment or interrupted treatment so that TB bacteria become resistant to anti TB drugs and then become MDR-TB. Bacteria that are in the body of MDR-TB patients are TB bacteria that are resistant to ATD so that patients are prone to transmit these bacteria to people around if not prevented. ${ }^{14}$ Primary transmission is the dominant cause of MDR-TB. ${ }^{15}$

\section{Recording and Reporting}

Recording and reporting in the internal environment is done every month and reporting to the health department is done every 3 months. The Perak Timur PHC said that there had never been a delay in recording and reporting. Good recording and reporting is very important for effective patient management. Effective program monitoring is influenced by a good recording and calling system. This system also ensures patient treatment quality and information-sharing between health centers. ${ }^{16}$

\section{Conclusions}

Generally, both PHCs having good TB program management but the Perak Timur PHC tends to be more flexible towards patients while the Sawahan PHC tends to be stricter towards patients.

\section{References}

1. World Health Organization. Tuberculosis. 2018. Available from https://www.who.int/news-room/factsheets/detail/tuberculosis. Accessed: July 2019.

2. World Health Organization. TB-a global emergency. Geneva: WHO; 1994.WHO/TB/94.177.

3. Ministry of Health of the Republic of Indonesia. Infodatin 2015. Available from

http://www.depkes.go.id/resources/dow nload/pusdatin/infodatin/infodatin_tb.p df. Accessed: July 2019.

4. Ministry of Health of the Republic of Indonesia. Peraturan Menteri Kesehatan RI nomor 75 tahun 2014 tentang Pusat Kesehatan Masyarakat.

5. Rahman LA, Kholis FN, Hariyana B. Analisis Manjemen Pelaksanaan Program Penanggulangan Tuberkulosis di Puskesmas Kota Semarang. Skripsi., Universitas Diponegoro di Semarang; 2017.

6. Ministry of Health of the Republic of Indonesia. Strategi nasional Pengendalian TB di Indonesia. 2014. Jakarta: Ministry of Health of the Republic of Indonesia.

7. Ministry of Health of the Republic of Indonesia. Peraturan Menteri Kesehatan RI nomor 67 tahun 2016 tentang penanggulangan TB.

8. Amenuvegbe GK, Francis A, Fred B. Low tuberculosis case detection: a community and health facility based study of contributory factors in the Nkwanta South district of Ghana. BMC Res Notes 2016;9:330-6.

9. Dabaro D. Factors affecting tuberculosis case detection in Kersa District,
South West Ethiopia. J Clin Tuberc Other Mycobact Dis 2017;9:1-4.

10. Shalsabila M, Cahyo K, Indraswari R. Beberapa Faktor yang Mempengaruhi Pencapaian Target CDR oleh Kader TB 'Aisyiyah dalam Penemuan Kasus TB di Kota Semarang. Jurnal Kesehatan Masyarakat 2018 6:582-56

11. Eddabra R, Benhassou HA. Rapid molecular assays for detection of tuberculosis. Pneumoniavol 2018;10:1-12.

12. Naim N, Dewi NU. Performas Tes Cepat Molekuler dalam Diagnosa Tuberkulosis di Balai Besar kesehatan Paru Masyarakat Makasar. Jurnal Media Analis Kesehatan 2018;9:11322.

13. Mansur M, Khadijah S, Rusmalawaty R. Analisis Penatalaksanaan Program penanggulangan Tuberkulosis Paru dengan Strategi DOTS di Puskesmas Desa Lalang kecamatan medan Sunggal Tahun 2015. Media Neliti 2015; 1-10.

14. Fox GJ, Schaaf HS, Mandalakas A, et al. Preventing the spread of multidrugresistant tuberculosis and protecting contacts of infectious cases. Clin Microbiol Infect 2017;23:147-53.

15. Kendall EA, Fofana MO, Dowdy DW. Burden of transmitted multidrug resistance in epidemics of tuberculosis: a transmission modeling analysis. Lancet Respir Med 2015;3:963-72.

16. World Health Organization. Implementing The WHO Stop TB Strategy: A handbook for national tuberculosis control programs. Geneva: World Health Organization; 2008. 